\title{
PARTIAL RESISTANCE OF SOYBEAN LINES TO ASIAN RUST AND WHITE MOLD
}

\section{RESISTÊNCIA PARCIAL DE LINHAGENS DE SOJA À FERRUGEM ASIÁTICA E MOFO BRANCO}

\author{
Juliana Araújo Santos MARTINS ${ }^{1}$; Augusto Borges e ALVES ${ }^{2}$; Michel GARCEZ²; \\ Fernando Cezar JULIATTI ${ }^{3}$ \\ 1. Professora, Doutora, Instituto Federal do Triangulo Mineiro - IFTM - Campus Uberlândia, Uberlândia, MG, Brasil; 2. Engenheiro \\ Agrônomo IFTM - Campus Uberlândia, Uberlândia, MG, Brasil; 3. Professor Titular, Instituto de Ciências Agrárias - ICIAG - UFU, \\ Pesquisador 1D do CNPq.
}

\begin{abstract}
Soybean Asian rust and white mold stand out to cause great problems to soybean producing regions in Brazil. The aim of this study was to evaluate the partial resistance of soybean lines to Asian rust and white mold. In order to assess the resistance of soybean to Asian rust, 19 early maturing soybean lines were used in an experiment in a greenhouse. Four severity evaluation were carried and the area under the disease progress curve was calculated. The productivity of those lines was evaluated in the field. In a second experiment, the resistance to Sclerotinia sclerotiorum was assessed under greenhouse conditions. When the plants were in the V2 stage, the inoculation was carried by cutting the main stem and inserting a ferrule containing the fungal mycelium. Seventeen soybean lines and the controls Emgopa 316 and Nidera RR 7255 were evaluated. The averages were grouped by the Scott Knott test by using the software Assistat. The lines L203 and L279 showed partial resistance to Phakopsora pachyrhizi and good productivity. The inoculation method was efficient in assessing the resistance to S. sclerotiorum. The lines L203, L268, L266, L226, L144 and L267 were resistant to the infection of S. sclerotiorum.
\end{abstract}

KEYWORDS: Glycine max. Phakopsora pachyrhizi. Sclerotinia sclerotiorum. Soybean resistance to disease.

\section{INTRODUCTION}

Brazil is the world's second largest producer of soybeans, being this the country's main export crop. In the season 2016/2017, approximately 33.89 million hectares were grown, reaching a production of 113,923 million tons of grain (CONAB, 2017). According to Juliatti et al. 2005, the economic exploitation of its potential yield $\left(4,000 \mathrm{~kg} \mathrm{ha}^{-1}\right)$ is hardly achieved since the world average yield has been of 2,200 kg ha' ${ }^{-1}$ Among the main factors that limit the performance, profitability and success of soybean production stand out the diseases.

Soybean Asian rust, caused by Phakopsora pachyrhizi H. Sydow \& P. Sydow, is one of the most important problems for agribusiness of the main soybean producing countries since it can cause strong reductions in productivity, with negative effects on the producer profitability and on the country's economy (JULIATTI et al., 2004). In the Brazilian conditions, the main aggravating factors for controlling the Asian rust are the territorial extension of crops and continued monoculture, favoring higher inoculum production and its dissemination, in addition to the appearance of different pathogen races. The favorable climate, failures in fungicide applications, high plant density, sowing period, in addition to the survival of the pathogen in volunteer soybean plants or other host species that survive in the period between crops, are the factors that reduce the disease control efficiency (UNFRIED, 2007).

Among the recommended soybean cultivars, there are not still any of them with a resistance level dismissing the use of fungicides to control the soybean rust. This is due in part to the recent occurrence of the disease in the country, but also because the fungus $P$. pachyrhizi has several breeds with multiple virulence genes (SINCLAIR; HARTMAN, 1995). The use of fungicides with different classes and modes of action is the corrently main form of control (MILES et al., 2007). However, these fungicides have limitations due to the high cost and difficulty in their management by the soybean producers. In addition, it increases the concern about the pollution of soil and water, and the toxicity to plants, humans and animals.

The white mold is caused by the fungus Sclerotinia sclerotiorum (Lib.) de Bary and stands out among the most important diseases of soybean, causing severe damage when the environmental conditions favor its development (ARRUDA, 2014). The most vulnerable stage of infection can be observed from the full flowering $\left(\mathrm{R}_{2}\right)$ to the full seed $\left(\mathrm{R}_{5}\right)$. In high humidity conditions, the fungus can colonize healthy tissues between 16 and 24 hours after infection of the senescent floral tissue; in dry conditions, the progress of the disease can be 
slowed or stalled, but it is resumed when in high humidity conditions (JULIATTI et al. 2013).

Soybean genetic resistance to $S$. sclerotiorum has been assessed in field, greenhouse and laboratory conditions, with responses that range from the complete susceptibility to the high resistance to the pathogen. Therefore, the host resistance is the control method more reliable and economical for the soybean producer because it does not require any specific additional handling; however, its use for white mold control is still scarce since there is a total lack of information about the Brazilian germplasm (JULIATTI, 2014). Thus, the aim of this study was to evaluate the partial resistance of soybean lines to Asian rust and white mold.

\section{MATERIAL AND METHODS}

In order to evaluate the resistance to soybean Asian rust, we used 17 early maturing lines from the Programa de Melhoramento Genético de Soja (Soybean Breeding Program) of the Universidade Federal de Uberlândia (UFU), coordinated by the Professor Fernando Cezar Juliatti. The cultivars Nidera $7255 \mathrm{RR}$ and Anta 82 RR (Table 1) were used as controls.

Table 1. Lines and crosses Soybean Breeding Program used in the experiment.
Lines
Crosses

\begin{tabular}{cc}
\hline Anta 82 RR & - \\
Nidera 7255 RR & - \\
L224 & Luziânia x Potenza F7 \\
L203 & Luziânia x PotenzaF7 \\
L268 & Caiapônia x Potenza F7 \\
L218 & Luziânia x Impacta F7 \\
L266 & Caiapônia x Potenza F7 \\
L162 & Luziânia x Impacta F7 \\
L231 & Caiapônia x IAC100 F7 \\
L226 & Luziânia x Potenza F7 \\
L144 & Caiapônia x IAC100 F7 \\
L216 & Luziânia x Potenza F7 \\
L166 & Caiapônia x IAC100 F3 \\
L269 & Caiapônia x Potenza F7 \\
L267 & Caipônia x Potenza F7 \\
L254 & Luziânia x PotenzaF7 \\
L279 & CaiapôniaxPotenza F7 \\
L104 & Luziânia x Impacta F7 \\
L296 & Caiapônia x IAC100 F7 \\
\hline
\end{tabular}

The experiment was conducted in a greenhouse and the sowing was carried out in sowings of 72 cells containing Plantmax ${ }^{\circledR}$ as susbtrate. When the plants presented the second expanded trifoliate (21days), the leaves were inoculated with the suspension of $P$. pachyrhizi adjusted to $0.8 \times 105$ urediniospores $\mathrm{mL}^{-1}$ with approximately $90 \%$ of germination, being dispersed in $0.5 \%$ Tween 20 . Spraying was conducted using a $1.0 \mathrm{~L}$ hand sprayer. After inoculation, the plants remained in the greenhouse in a temperature of $30 \pm$ $3^{\circ} \mathrm{C}$, with wetness shifts of 15 minutes every 3 hours for 12 hours per day.
The experimental design was a randomized complete block with four replications, each plot consisting of six plants. The severity of the Asian rust was visually estimated using a leaflet of the second expanded trifoliate in all plants of each plot. Disease severity was rated with the help of a standard area diagram proposed by Juliatti et al. (2009). The area under the disease progress curve (AUDPC) was used to describe the epidemic (SHANNER; FINLEY, 1977).

An experiment for the evaluation of productivity was carried out in the field. A conventional soil tillage was conducted with two heavy and a light harrowing. The fertilization was 
performed at the same time of sowing using single superphosphate, potassium chloride and urea. The seeds were distributed manually in the planting furrows at a depth of $3 \mathrm{~cm}$, in the second half of November 2014. The weed control was carried out with the application of the herbicides Clethodim + Fenoxaprop EC (1.0 $\left.\mathrm{L} \mathrm{ha}^{-1}\right)$ and Lactofen EC (0.75 $\left.\mathrm{L} \mathrm{ha}^{-1}\right)$. The control of pests and insects was conducted with the application of the insecticide Deltamethrin EC (0.4 $\left.\mathrm{L} \mathrm{ha}^{-1}\right)$ and Methamidaphos $\left(0.4 \mathrm{~L} \mathrm{ha}^{-1}\right)$. The experimental design used was the randomized complete block design with three replications, each plot consisting of four lines of 5.0 m length.

Data underwent a variance analysis and the similar averages were grouped by the Scott Knott's test at 5\% probability, using the Assistat software (SILVA; AZEVEDO, 2009). The AUDPC variable was transformed into square root of $(x+10)$.

In a second trial, the resistance to $S$. sclerotiorum was evaluated in a greenhouse at UFU, from April to June 2015. The inoculum was provided by the mycology and plant protection laboratory of the UFU (LAMIP). The sclerotia were disinfected in 50\% alcohol and in $0.5 \%$ sodium hypochlorite diluted in sterile distilled water during 30 and 60 seconds respectively. Subsequently, they were transferred to Petri dishes containing PDA and incubated at $22 \pm 3^{\circ} \mathrm{C}$ in 12 hours of photoperiod for the mycelium formation.
Seventeen (17) UFU breeding program and the controls Emgopa 316 and Nidera 7255 RR, respectively tolerant and susceptible to $S$. sclerotiorum were evaluated (Table 1). The experimental design was a randomized complete block with four replications and six plants per replication. For the soybean sowing, 72-cell trays filled with substrate were used, in which 3 seeds per cell were placed; subsequently, the thinning was carried out, leaving one plant per cell. The plants were placed in a greenhouse with daily irrigation. When the plants were at the V2-V3 stage, i.e., second and third trifoliate (32 days), the main stem was cut horizontally. The inoculation with a 200microliter pipette tip containing fungal mycelium was performed, which was prepared on the cut stem (CHAWLA et al, 2013; KOGA et al, 2014).

The evaluations were performed at 12 days after inoculation (DAI) when the lesions were measured $(\mathrm{cm})$ by using a ruler, transformed to $\sqrt{(x+10}$, and grouped by the Scott Knott test at $5 \%$ probability using the software Assistat.

\section{RESULTS AND DISCUSSION}

The lines L203 and L279 showed the lowest AUDPC values compared to the others, evidencing significantly resistance to the pathogen. These lines were placed also in the group that showed higher productivity (Table 2 ).

Table 2. The area under the Soybean Asian rust progress curve (AUDPC) and productivity.

\begin{tabular}{cccc} 
Lines & Crosses & AUDPC & $\begin{array}{c}\text { Productivity } \\
\text { Kg hectare }^{-1}\end{array}$ \\
\hline Anta 82 RR & - & $11,41 \mathrm{~b}$ & $1597 \mathrm{a}$ \\
Nidera 7255 RR & - & $10,13 \mathrm{~b}$ & $1514 \mathrm{a}$ \\
L224 & Luziânia x Potenza F7 & $12,20 \mathrm{~b}$ & $1953 \mathrm{a}$ \\
L203 & Luziânia x Potenza F7 & $4,55 \mathrm{a}$ & $1510 \mathrm{a}$ \\
L268 & Caiapônia x Potenza F7 & $15,64 \mathrm{c}$ & $1709 \mathrm{a}$ \\
L218 & Luziânia x Impacta F7 & $11,37 \mathrm{~b}$ & $1562 \mathrm{a}$ \\
L266 & Caiapônia x Potenza F7 & $11,45 \mathrm{~b}$ & $1002 \mathrm{~b}$ \\
L162 & Luziânia x Impacta F7 & $14,41 \mathrm{~b}$ & $1300 \mathrm{~b}$ \\
L231 & Caiapônia x IAC100 F7 & $27,11 \mathrm{c}$ & $1180 \mathrm{~b}$ \\
L226 & Luziânia x Potenza F7 & $14,00 \mathrm{~b}$ & $1216 \mathrm{~b}$ \\
L144 & Caiapônia x IAC100 F7 & $20,47 \mathrm{c}$ & $1076 \mathrm{~b}$ \\
L216 & Luziânia x Potenza F7 & $24,66 \mathrm{c}$ & $1812 \mathrm{a}$ \\
L166 & Caiapônia x IAC100 F3 & $9,83 \mathrm{~b}$ & $1272 \mathrm{~b}$ \\
L269 & Caiapônia x Potenza F7 & $14,99 \mathrm{c}$ & $1612 \mathrm{a}$
\end{tabular}




$\begin{array}{lccc}\text { L267 } & \text { Caiapônia x Potenza F7 } & 14,08 \mathrm{c} & 1154 \mathrm{~b} \\ \text { L254 } & \text { Luziânia x Potenza F7 } & 20,68 \mathrm{c} & 1497 \mathrm{a} \\ \text { L279 } & \text { Caiapônia x Potenza F7 } & 5,03 \mathrm{a} & 1582 \mathrm{a} \\ \text { L104 } & \text { Luziânia x Impacta F7 } & 20,38 \mathrm{c} & 2252 \mathrm{a} \\ \text { L296 } & \text { Caiapônia x IAC100 F7 } & 22,13 \mathrm{c} & 1453 \mathrm{a}\end{array}$

$\mathrm{ns}, *$ and $* *=$ no significative to $5 \% \mathrm{~F}$ test, and signficative to 5 and $1 \%$ of probability, respectively.

$* \mathrm{CV} \%=25.39 ; *$ The averages followed by the same letter do not differ statistically from each other. The Scott-Knott Test at the 5\% probability level was applied.

The lines L224 and L104 stood out for being the most productive (Table 2). However, they presented the highest values of AUDPC, i.e., showed to be less resistant to $\mathrm{P}$. pachyrhizi. According to Azevedo et al., (2004), researches indicate that soybean Asian rust is only detected using a simple visual observation from a severity at $5 \%$, which is a very high and risky level to start the chemical control. Therefore, the cultivation of materials with such characteristics must be done carefully since the producers do not make effective use of monitoring systems to control the disease.

Studying the interaction between partial genetic resistance and fungicide in controlling Asian rust, Silva et al. (2007) observed significant effects of the cultivars, fungicide and interaction between these two factors for AUDPC and productivity, standing out the cultivars IAC-100, Potenza and UFUS-Impacta as partially resistant to the Asian rust. Comparing this result with those showed in Table 2, we realized that there were differences in the behavior of lines in response to AUDPC and productivity since the lines Potenza and UFUSImpacta used in the L224 and L104 presented, respectively, low AUDPC values and high productivity; in this study, these values were different.

Regarding the white mold, we noted that the genotype Emgopa 316 showed to be moderately resistant to the disease when compared to the susceptible genotype Nidera 7255 RR (Table 3).

Table 3. The averages lesion sizes $(\mathrm{cm})$ at 12 days after inoculation (D.A.I).

\begin{tabular}{cc}
\hline Lines & 12 D.A.I \\
\hline Emgopa 316 & $2,86 \mathrm{~b}$ \\
Nidera 7255 RR & $4,41 \mathrm{a}$ \\
L224 & $2,54 \mathrm{~b}$ \\
L203 & $2,26 \mathrm{c}$ \\
L279 & $2,91 \mathrm{~b}$ \\
L268 & $2,33 \mathrm{c}$ \\
L218 & $2,66 \mathrm{~b}$ \\
L266 & $2,16 \mathrm{c}$ \\
L162 & $2,94 \mathrm{~b}$ \\
L231 & $2,51 \mathrm{~b}$ \\
L226 & $1,92 \mathrm{c}$ \\
L144 & $2,12 \mathrm{c}$ \\
L216 & $2,74 \mathrm{~b}$ \\
L166 & $2,73 \mathrm{~b}$ \\
L269 & $2,57 \mathrm{~b}$ \\
L267 & $1,85 \mathrm{c}$ \\
L254 & $2,94 \mathrm{~b}$ \\
L279 & $2,92 \mathrm{~b}$ \\
L104 & $2,54 \mathrm{~b}$ \\
L296 & $3,06 \mathrm{~b}$ \\
\hline
\end{tabular}

Obs.: se a medida de lesão foi tomada com uma régua em centímetros $(1,0 \mathrm{~cm}=0,01 \mathrm{~m})$, não vejo a necessidade de usar mais que duas casas decimais na apresentação dos resultados

$*$ CV\% $=24,75 ; *$ The averages followed by the same letter do not differ statistically from each other. The Scott-Knott Test was applied at the $5 \%$ probability level. 
However, it presented value of lesion size greater than some lines evaluated. In studies carried out in the field by Garcia, Juliatti (2012) and Juliatti et al. (2013), the genotype Emgopa 316 was also considered resistant to the disease when compared to other genotypes. In a study conducted in the crop season 2010/ 2011 using cultivar NA 7255 RR, Teles et al. (2013) observed a higher incidence of sclerotia in seed samples. The same author reported that the amount of sclerotia in the sample was not necessarily correlated with the incidence of $S$. sclerotiorum in the mycelial form in soybean seeds. In other study, Juliatti et al. (2014), evaluating the resistance of soybean genotypes to $S$. sclerotiorum, observed that there was no relation between lesion size and the number of sclerotia in the soybean stem.

When the lines were compared to the cultivar Nidera 7255 , considered the susceptibility pattern, all of them showed to be resistant to $S$. sclerotiorum, especially the lines L203, L268, L266, L226, L144 and L267, which presented smaller lesion sizes.

The temperature detected between the inoculation and experiment evaluation periods varied from 17 to $28^{\circ} \mathrm{C}$. According to Link, Johnson
(2015), the optimal temperature for mycelial development of $S$. sclerotiorum must be between 12 and $24^{\circ} \mathrm{C}$. This fact may explain in part the occurrence of smaller lesions in plants, as in a study conducted in field by Juliatti et al. (2014), in which the lesions ranged from six to $11 \mathrm{~cm}$. However, even under the conditions of which the study was carried out, the genotypes of smaller and greater partial resistance to the pathogen could be distinguished into in the greenhouse experiment.

\section{CONCLUSIONS}

In the field trail the lines L203 and L279 showed partial resistance to $P$. pachyrhizi and were as productive as the cultivars Nidera $7255 \mathrm{RR}$ and Anta 82 RR.

In the greenhouse trial all lines showed to be resistant to $S$. sclerotiorum, especially the lines L203, L268, L266, L226, L144 and L267, with smaller injury sizes.

The cultivar Nidera 7255 RR demonstrated high standard of susceptibility to $S$. sclerotiorum when compared to the resistant control Emgopa 316 and evaluated lines.

RESUMO: A Ferrugem Asiática e o Mofo-Branco da soja se destacam por causar grandes problemas em regiões produtoras de soja do Brasil. O objetivo deste trabalho foi avaliar a resistência parcial de linhagens de soja à ferrugem asiática e ao mofo branco da soja. Para avaliação da resistência à ferrugem asiática da soja foram utilizadas 19 linhagens de ciclo precoce em ensaio em casa de vegetação. Foram realizadas quatro avaliações de severidade e calculada a área abaixo da curva de progresso da doença. Avaliou-se a produtividade dessas mesmas linhagens a campo. Em um segundo ensaio, avaliou-se a resistência à $S$. sclerotiorum em casa de vegetação. Quando as plantas estavam em V2 realizou-se a inoculação através do corte da haste principal e inserção de ponteira contendo o micélio do fungo. Foram avaliadas 18 linhagens de soja e duas testemunhas, Emgopa 316 e Nidera RR 7255. As médias foram comparadas pelo teste de Scott Knott, através do Assistat. As linhagens L203 e L279 demonstraram resistência parcial à $P$. pachyrhizi e apresentaram boa produtividade. O método de inoculação mostrou-se eficiente na avaliação da resistência à $S$. sclerotiorum. As linhagens L203, L268, L266, L226, L144, L267 mostraram-se resistentes à infecção por S. sclerotiorum.

PALAVRAS-CHAVE: Glycine max. Phakopsora pachyrhizi. Sclerotinia sclerotiorum. Resistência da soja a doenças.

\section{REFERENCES}

ARRUDA, J. H. Ação de agroquímicos no controle do mofo branco na soja. Pato Branco: Universidade Tecnológica Federal do Paraná, 2014. 58p. Dissertação de Mestrado.

CHAWLA, S. et al. A Public Program to Evaluate Commercial Soybean Cultivars for Pathogen and Pest Resistance. Plant Diase, Illinois, v. 97, n. 5, p. 1-11, 01 maio 2013. University of Illinois. Disponível em: <http://apsjournals.apsnet.org/doi/abs/10.1094/PDIS-05-12-0479-FE>. Acesso em: 24 set. 2014.

CONAB - Companhia Nacional de Abastecimento - Ministério da Agricultura Pecuária e Abastecimento. Acompanhamento da safra brasileira. Disponível em: https://www.conab.gov.br/index.php/info-agro/safras. Acesso: 14/04/2018. 
GARCIA, R. A.; JULIATTI, F. C. Avaliação da resistência da soja a Sclerotinia sclerotiorum em diferentes estádios fenológicos e períodos de exposição ao inóculo. Trop. plant pathol., Brasília, v. 37, n. 3, p. 196203, June 2012 .

JULIATTI, F. C.; POLIZEL, C. A.; JULIATTI, C. F. Manejo integrado de doenças na cultura da soja, Uberlândia: EDUFU, 2004.

JULIATTI, F. C.; POLIZEL, C. A.; BALARDINS, R. S.; VALE, F. X. R. Ferrugem da soja - Epidemiologia e manejo para uma doença reemergente. In: Luz, W.C.; Fernandes, J.M.C.; Prestes, A. M.; Picinini, E.C. Revisão Anual de Patologia de Plantas. Passo Fundo, v. 13, p. 351 - 395. 2005.

JULIATTI, F. C. et al. Eficiência dos fungicidas aprovados na RPSRCB no controle da ferrugem asiática da soja, em Uberaba -MG. Universidade Federal de Uberlândia, p.79-91. In: Documentos... Embrapa-Soja, Resultados dos ensaios cooperativos para o controle da ferrugem asiática da soja, safra 2008-9. ISSN 21762937, versão eletrônica, Nov. 2009, (documento n. 317).

JULIATTI, F. C.; CAIRES, A. M.; JULIATTI, B. C. M.; BORIN, M. R.; SOUZA FILHO, D. J. de. Reação de genótipos de soja transgênicos e convencionais à podridão-branca da haste. Bioscience Journal, v. 29, p. 921931, 2013.

JULIATTI, F. C. et al. Métodos de Inoculação e avaliação da resistência de genótipos de soja à Sclerotinia sclerotiorum. Bioscience Journal, Uberlândia, v. 30, n. 4, p. 958-968, 02 maio 2014.

KOGA, L. J. et al. Mycelial compatibility and aggressiveness of Sclerotinia sclerotiorum isolates from Brazil and the United States. Pesquisa Agropecuária Brasileira, Brasília, v. 49, n. 4, p. 265-272, 01 abr. $2014 .$.

LINK, V. H.; JOHNSON, K. B. White mold (Sclerotinia). Disponível em:

$<$ http://www.apsnet.org/edcenter/intropp/lessons/fungi/ascomycetes/Pages/WhiteMold.aspx>. Acesso em: 20 jul. 2015. https://doi.org/10.1590/S0100-204X2014000400004

MILES, M. R. et al. International fungicide efficacy trials for the management of soybean rust. Plant Disease, Sain Paul, v. 91, p. 1450-8. 2007.

SHANNER, G.; FINLEY, R. F. The effects of nitrogen fertilization on the expression of slow-mildewing in know wheat. Phytopathology, St. Paul, v. 70, p. 1183-86, 1977.

SILVA, V. A. S.; JULIATTI, F. C.; SILVA, L. A. S. Interação entre resistência genética parcial e fungicidas no controle da ferrugem asiática da soja. Pesquisa agropecuária brasileira, Brasília, v. 42, n. 9, p. 1261-1268, set. 2007.

SILVA, F. A. S. e; AZEVEDO, C. A. V. de. Principal components analysis in the software assistatstatistical assistance. In: 7th World Congress on Computers in Agriculture, 2009, Reno. Proceedings of the 7th World Congress on Computers in Agriculture. St. Joseph: ASABE, 2009. v. CD-Rom. p.1-5.

SINCLAIR, J. B.; HARTMAN, G. L. Management of Soybean Rust.In: SOYBEAN RUST WORKSHOP, 1995, Urbana. Proceedings... Urbana: College of Agricultural, Consumer and Environmental Sciences, 1995. p. 6-10.

TELES, H. F. et al. Incidence of Sclerotinia sclerotiorum ad the physical and physiological quality of soybean seeds based on processing stages. Journal of Seed Science, v. 35, n. 4, p.409-418, 2013. Disponível em: <http://www.scielo.br/pdf/jss/v35n4/01.pdf>. Acesso em: 08 jul. 2014. https://doi.org/10.1590/S2317-15372013000400001

UNFRIED, J. R. Estratégias para seleção de linhagens experimentais de soja para tolerância à ferrugem e associações com outras doenças. 2007. 220 f. Tese (Doutorado em Genética e Melhoramento de Plantas) Escola Superior de Agricultura "Luiz de Queiroz", Universidade de São Paulo, Piracicaba. 2007. 